\title{
THE IN LOCO PARENTIS ROLE OF THE TEACHER: A RELATIONSHIP PERSPECTIVE
}

\author{
I.J. Oosthuizen \\ Dept. of Comparative Education and Educational Management \\ Potchefstroom University for CHE \\ POTCHEFSTROOM
}

\begin{abstract}
The parent (as the printan educator) as well as the teacher (as the secondan educator) functions: from independen societal units in their respectrve roles of educating the educand The teacher as an in loco parentis person has the right on the one hand to maintain order by means of school nules and the punishment of transgressors and on the other hand has a duty to carc for the safery of the educands. The parent and the teacher share a common goal: the maturing and the development of the educand. Whilst the nature of this parent-reacher co-operation is defined as a pannership, it is taking the technical esscentials of a pannership into account - more of a voluntan association. This generates the question wheiher the whole system of paren-ieacher co-operanon should not be reorganised on the basis of a tric parninership.
\end{abstract}

\section{PERSPECTIVE}

The parent-teacher relationship has as a common goal the education of the child. Although parent and teacher are united by this common purpose, practice has shown that undefined roles in the respective rights and obligations of the associates could lead to disharmony (Oosthuizen, 1990:74).

A few examples of where the infringement of one another's area of competency has caused disharmony in the past are court cases such as $S v$ Meeuwis (1970 4 SA 532 (T) and Tiffen $v$ Cilliers (1925 OPD 30). In the first-mentioned case the teacher involved exceeded her disciplinary mandate by not exercising corporal punishment in accordance with the regulations. After the boy's father had taken him to the district surgeon a court case followed. In Tiffen $v$ Cilliers the fact that the father refused that his child should be subjected to corporal punishment led to the expulsion of the pupil which resulted in a court case between the parent and the school principal.

In an effort to understand the respective areas of competence more specifically, this article will examine the role of the teacher as an in loco parentis person. To better understand this role it will be necessary to investigate the foundations of the respective 
societal unit's authority spheres as well as the nature of parent-teacher association. Parent-teacher co-operation is described in general terms as a partnership. When the word is analysed according to its juridical contents, it shows that the present form of parent-teacher co-operation is not a true partnership but has more the nature of a voluntary association. The very nature of a voluntary association tends to cause undefined (and sometimes even unstructured) roles of participation between the two associates - especially in the non-statutory forms of participation.

\section{EDUCATION AND THE SOCIETAL UNITS}

All societies consist of a variety of sub-societies such as the household (family), the church, the state, etc. Taljaard (in Mentz, 1990:13), defines a societal relationship as a relationship where people are bound by a common interest and are iointly set on obtaining the same goals. A societal relationship therefore results from a common motive which binds people together in corresponding actions. Taljaard (in Mentz, 1990:14), stipulates the characteristics of a societal relationship as follows:

* A societal relationship has a power structure

* A societal relationship is bound by a definite collectivity.

* A societal relationship has an interdependent connection.

* A societal relationship is structured.

Various of these societal relationships - each one chararacterised by its own, unique nature, and functioning sovereignly within its own sphere of activities - are involved in the education of the child. The four societal relationships which are mainly involved in educating the child are the household (family), the school, the church and the university (Van der Walt et al., 1982:87). This sphere of competence which is a characteristic of all societal relationships is known as sovereignty within own sphere. Even though there is a definite undercurrent of continuity among the different societal relationships, the sovereignty of each is at the same time a prerequisite for the proper functioning of a societal relationship. Although all the above-mentioned societal relationships have the same common goal in mind (educating the educand), each one functions in accordance with its own specific nature and purpose in society. For the purpose of this article the focus will fall on the role of the school (and the teachers) and the household (under control of the parents), as educators of the child.

\subsection{The family as a societal relationship}

Van der Walt et al. (1982:91) describes a household as a group of people consisting of 
a husband and wife and at least one child begotten (or adopted) by the parents. Within the loving atmosphere of the family circle, the child is educated by its parents to attain basic life skills and to become a suitable member of the society.

Because the household is the basic and first relationship where education takes place. it is called the primary educational institution and parents serve as primary educators.

\subsection{The role of the parent as the primary educator}

The Christian parent is obliged to educate and care for his child according to the Biblical guidelines and as a result of the promise he has made to God to do so. Apart from this, he is also juridically bound to educate and care for his children (Van der Vyver et al, 1985:611):

* It is expected from parents to care for, and watch over the bodily well-being of their children. They are also to educate their children towards acceptable bodily practices.

* Parents are to educate their children in virtues such as honesty, diligence and trustworthiness.

- Parents are obliged to expose their children to teaching and the development of their minds.

* The children are to be educated by their parents to live according to the acceptable cultural norms and values.

\subsection{The school as a societal relationship}

The school is described by Van der Walt et al. (1981:96) as a secondary societal relationship and its basic function is to teach the pupil in a teaching-learning situation. Teaching at schools is carried out purposefully, differentiated and in a specialised manner by professionally trained teachers (Louw, et al., 1983:46). According to Louw et al. (1983:46) education (and the teaching which might take place) at home functions intuitively and informally. The teacher is also responsible for the education of the pupils in the acceptable values and norms.

The teaching and education of the child in the school is exercised by the school as a societal relationship with its own (independent) function and purpose. As a societal 
The in loco parentis role of the teacher: a relationship perspective

relationship it functions with the sovereignty of its own authority in its own sphere of activities.

\section{PARENT-TEACHER ASSOCIATION}

The devolution of power to the South African parent as a user of the formal education in South Africa, has been receiving a high priority throughout our local educational history. One of the early statutory evidences for official parental participation in the formal education is a statute, promulgated in 1874 during the presidency of President T.F. Burgers of the South African Republic. Parental participation in school management was arranged by this law; in article 18 of the law it was stipulated that a "schoolcommissien" should be appointed in each community to communicate the parental desires. This board, consisting of six members, had to be members of the specific community. This principle of the parental voice in education was maintained and confirmed by several statutes - the latest of which was the Education Affairs Act (House of Assembly) of 1988.

This trend of parental participation in formal education is also known as a parentteacher partnership. Whereas the author previously compared it with the characteristics of a partnership (Oosthuizen, 1989:102), he is now of the opinion that the nature of the present parent-teacher relationship shows more similarities with an alternative form of co-operation. Taking the juridical essentials of a partnership into account it is wrong to speak of a parent-teacher partnership - mainly because the main aim of a partnership is to make a financial profit (Oosthuizen, 1988:252). The characteristic of a partnership to make profit is regarded a essential for the existence of a partnership. Oosthuizen (1988:252) as well as De Wet and Van Wyk (1978: 387) report that without the motive of profit there can be no partnership. According to Bamford (1982:5) the "object of making profits clearly distinguishes partnership from voluntary association". The object of the present parent-teacher relationship is vested in the educative and not in financial profit; it therefore cannot be labelled as a partnership. When attempting to label the present parent-teacher relationship, it would be more correct to call it a voluntary association. A voluntary association is juridically defined as a legal relationship based on an agreement between three or more persons set to meet a common object, which is "primarily other than the making and division of profits" (Bamford, 1982:117).

Judging the parent-teacher relationship by the essentials of the voluntary association as stipulated by Bamford (1982:117) shows the following similarities: 
- It is a voluntary association. The participation of parents in non-statutory bodies such as the TTA and the TAO is based on voluntary grounding.

- It is a legal relationship which is based on an agreement: The statutory say for parents was legally instituted by the Education Affairs Act (House of Assembly) No. 70 of 1988. As far as the non-statutory say is concerned, it was formally acknowledged by the National Education Policy Act, no. 39 of 1967, while the Federation of Parents' Associations of South Africa was formally acknowledged by the Minister of Education and Culture (House of Assembly) in November 1988.

Defining the parental role within the parent-leacher relationship, aspects such as the status, powers and functions of management councils were constituted in the Regulations relating to Management Councils (Regulations promulgated under the Education Affairs Act of 1988).

The rights and obligations of each of the two associates (Claassen, 1976:121) are determined to a large extent by means of statutory stipulations. Apart from the statutory stipulations, rights and obligations are determined by common law principles such as the in loco parentis principle. A definition of the in loco parentis principle includes the following:

- It is an agreement between three or more persons. The Regulations relating to Management Councils (Regulations in accordance with the Education Affairs Act of 1988) stipulates that a total number of between (a minimum of) 5 and (a maximum of) 13 members should serve on a management council. The number of parental participants in the non-statutory bodies is unlimited. Compared to this the required number of partners in a partnership is limited to a maximum of 20 .

- It is set to obtain a common objective. The common objective of this relationship is the forming of the educand into a mature and productive member of the society. To obtain this mutual objective, both parent and teacher associates of the voluntary association contribute in a specialised way to the achievement of the common objective. The parent as primary educator is basically involved in the cultural formation of the child and his education as a mature member of the community. Where the teacher is also involved in the education of the child, his basic function is that of developing the logical-analitical aspects of the educand (Van der Walt, 1982:96). This function is executed in a specialised and differentiated manner by teachers who were professionally trained to do so.

- Its object is primarily other than to make a profit and to divide the profits. The partnership's main object is to make a financial profit and to divide it amongst the 
members of the partnership. The voluntary association differs vitally from this essential: "The absence of a profit-making object distinguishes voluntary association from partnership" (Bamford, 1982:119).

The fact that a voluntary association does make a profit, does not destroy it as essentially being a voluntary association, as long as the profit-making is "merely incidental to its main object" (Bamford, 1982:119). Where parents and teachers cooperate in parents' associations such as TEMPA or the TAO, and they undertake money-making ventures (such as fetes or competitions), the profit-mating object is incidental to their mutual (and main) aim to make more effective education and teaching possible.

The real profit which comes from the parent-teacher co-operation, is not a financial one but a figurative profit - the maturing and preparing of the educand as a member of society. As in the case with the partnership, the co-members jointly contribute (Claassen, 1976:121) to obtain their mutual objective. The parent mas for instance contribute financially, while the teacher's main contribution is the logical-analytical development of the educand.

Because the parent is not professionally trained to provide the educand with specialised subject knowledge - preparing the educand for a specialised career - he is dependent on his professionally-trained associate - the teacher - for this purpose. While the teacher teaches (and educates) the educand, the parent is physically absent. The child as a minor is dependent on the guidance, protection and assistance of an adult. The teacher, professionally-trained to do so, is ideally suited to act in the place of the parent (in loco parentis).

\section{IN LOCO PARENTIS}

\subsection{Description}

Literally translated, the expression means 'in the place of the parent'. Black (1979:708) defines it as being "in the place of the parent; charged, factitiously with a parent's rights, duties, and responsibilities". Claassen (1976:218) defines it as: "In the place of the parent. Those who have been entrusted by the parents with the custody and control of children under age are said to stand in loco parentis to the children." People who are acting in loco parentis are inter alia teachers and hostel staff (Hosten et al., 1979:502).

Taking the preceding theory of societal relationships, the parent-teacher relationship 
and the definition of in loco parentis into account, the practical implications of the in loco parentis theory are as follows:

- The in loco parentis person does not replace the parent - the parent as the primary educator can never be replaced. The parent is responsible and liable to God and the law to fulfil his duty as the parent and custodian of his child. The in loco parentis person (the teacher) who stands in an association with the parent acts on behalf of his associate to educate and teach his child professionally and in the physical absence of the parent.

- The right vested in the teacher as an in loco parentis person to exercise authority over the pupil, is both delegated power and original power. It is delegated to him by his associate, the parent, and it is original since the teacher acts from within the societal relationship of the school and its sovereign sphere (with its own power structure).

The very nature and way in which the teacher exercises his authority is qualified bv the aim and function of the school as a societal relationship.

Maintaining discipline in school can therefore be described as being of a peculiar character - especially when compared with the maintenance of discipline in the family and the state.

- The teacher is also under the obligation to provide custody for the pupil as a minor for the time that he is entrusted to the teacher. There is a duty of care on the teacher for the physical and mental protection of the pupil. This duty of care can also be derived from the teacher's obligation to his associate, the parent, to provide a safe environment where the intellectual development, resulting from teaching, can be maximal.

- A résumé of the rights and liabilities of the teacher as an in loco parentis shows that the teacher has the right to maintain school rules and punish transgressors. On the other hand he is liable to provide a safe environment for the pupil.

\subsection{The teacher as a person in authority}

The existence and functioning of any community (i.e. a societal relationship like the school) is dependent on the presence of order in the community. This community order is dependent on the sensitive balance between the complexity of reciprocal rights and the duties of the community members. To ensure that an equilibrious balance is 
maintained, rules and regulations - and punitive actions when they are disregarded are a precondition. The necessity to enforce rules and regulations by disciplinary actions, is - according to Hosten et al. (1979:14) - a result of man's sinful nature and his inclination to disobedience. This attitude (which is present in pupils at school) necessitates the presence of school rules coupled with applicable punitive measures at school. Punishment is applied by the educator not because "kinders nie kin nie, maar omdat hulle nie wíl kan nie" (Van der Walt et al., 1982:249).

The teacher has a juridical mandate for the drafting of school rules and the administration of punishment. This juridical mandate is mainly grounded on legislation, common law principles (of which the in loco parentis principle is the most important one) and the affirmation of the judiciary. This article is mainly focused on the in loco parentis role of the educator.

\subsubsection{School rules}

School rules can be defined as those measures which are exercised by the teacher to maintain order and discipline among the pupils. "Effective discipline programs are built around a philosophy that is communicated by a few clear, concise rules" (Fellmy, 1983:68).

Apart from the fact that the teacher is providing a safe and orderly place for the children of his associate, the parent, he is also expressing to the pupils and their parents what the educational aims are (Partington, 1984:125).

A few examples of school rules are (Oosthuizen, 1990:119):

- rules in connection with school uniforms;

- rules concerning the physical appearance of pupils;

- rules concerning the time when the school commences and closes;

- rules concerning the behaviour of pupils inside as well as outside the classroom;

- rules regulating pupil behaviour during extra-mural activities;

- rules prescribing how and when homework should be completed.

The requirements for the validity of such domestic school rules are dependent on a few pre-conditions (Prinsloo, 1989:82; Oosthuizen, 1990:124; Van Wyk, 1987:114; Bray, 1988:200-201):

- In terms of regulation 3(1) of the Regulations Relating to the Control of Pupils at, Suspension and Expulsion of Pupils from, and Meeting out of other Punishment to 
Pupils Attending Public Schools, these rules are to be approved by the specific director of education.

- According to the same regulations these rules are to be approved by the governing body of the school who act as representatives of the parental community. The nature of the parent-teacher association is strongly emphasised by this ruling since both parent and teacher participate in formulating the rules.

- School rules are to be in line with educational laws and regulations.

- School rules should be made known to all involved and should be as clear as possible.

- The contents of school rules should be as fair and reasonable as possible.

When pupils do not comply with valid rules, the teacher as an in loco parentis person, and because of the statutory powers vested in him, holds the right to exercise reasonable discipline to enforce the rules.

\subsubsection{The teacher as a disciplinarian}

The word discipline, transiated from the Latin word disciplina, literally means to learn, to educate, to punish etc. (Postma, s.a.:93). It is therefore clear that the process of teaching and education is closely associated with the act of discipline.

A situation and climate of order is a prerequisite for any form of learning to take place. Barnett (as quoted by Griessel, 1975:56) says that "order is certainly not teaching, but it is clearly the first indispensable condition of true efficiency".

The in loco parentis person is responsible to his associate, the parent, for the efficient teaching of the pupil entrusted to him. To be successful in this, he has to create a disciplined atmosphere. Ways in which this is to be done are:

- Non-verbal ways of communicating disapproval, including the direct eye contact or 'eyeballing' of the pupil, the nodding of the head, the lifting of an eyebrow and the pointing of a finger.

- The isolating (in class) of a transgressor from his friends (or even with the whole class). 
- The teacher could ignore minor incidents, especially where it becomes clear that a pupil did something wrong by mistake or as a result of poor judgement.

- A very sound way of maintaining discipline, is the principle of positive enforcement or the so-called 'catch'em being good principle'.

- The verbalisation of warnings and advice to the pupil.

- Detention.

- Exclusion from certain advantages.

- Corporal punishment.

- Expulsion from school

- Exclusion from school. (see Shrigley, 1985:27; McDaniel, 1986:66.)

\subsubsection{Corporal punishment}

Although the issue of corporal punishment is regulated by departmental regulations, the original mandate to administer corporal punishment is embedded in the common law principle of in loco parentis. According to our common law a parent holds the right to administer "matige en redelike" (Rex v Muller 19484 SA 860 (O) and S. v Lekgathe 19823104 (BT)) corporal punishment to their children. Judge Horwitz extended this principle to the teacher as an in loco parentis person in the best interest of the school as an institution and in order that the pupil might be reformed (Rex $v$ Muller 19484 SA $862(\mathrm{O}))$. This viewpoint of judge Horwitz is a confirmation of the role of the in loco parentis person as a disciplinarian within the parent-teacher association.

Even although this authority is delegated to the teacher by his parent-associate, he also holds an original and independent right to discipline on the grounds of his position as a teacher ( $R v$ Muller 19484 SA $862(\mathrm{O}))$. This orginal mandate to the punishment of the pupil means that the parents cannot intervene in the way in which a teacher exercises its disciplinary measures. "A father cannot tell the teacher how or when to punish a child. The responsibility for deciding on punishment at school is the school's" (Kahn, 1982:312). Even though the teacher has a mandate to administer corporal punishment he is responsible for administering it, motivated by the mutual object that he shares with his associate : the maturing and the development of the child. Corporal punishment should therefore never result from a motive such as revenge or recompence.

An example of some of the guidelines concerning the juridically correct ways in which corporal punishment is to be administered, is found in regulation 4 of the Regulations 
Relating to the Pupils at, Suspension and Expulsion of Pupils from, and the Meeting out of other Punishments to Pupils in Public Schools.

\subsubsection{Suspension and expulsion}

Suspension is defined as the "temporary prohibition of a pupil" to attend a particular public school or state-aided school or a hostel. Expulsion (and exclusion) is described as "the permanent prohibition of a pupil to attend a public school, a state-aided school or a hostel" (in Regulation 3(1) of the Regulations Relating to the Control of Pupils ...).

The common law, rooting the in loco parentis principle, is qualified by regulations. especially in the case of the procedural steps during the process of expulsion or suspension.

The teacher as an in loco parentis person acts on behalf of his associate - the parent - to attain their common goal of teaching and educating his child when he disciplines him to the required performance and behaviour. At a certain point - where the misbehaviour of an individual pupil disrupts the order to such an extent that the learning climate is continuously damaged and learning suffers - the teacher as an in loco parentis, has to 'turn his back' on his associate (the parent of the individual pupil) for the sake of the 'body corporate' - the group and its interests. Prinsloo (1989:78) says that the teacher's obligation to take care of the school as an institution is "vested with the necessary authority to protect itself against the pranks of the young, their vandalism and the consequences of their unbridled exuberance and lack of discipline". This is an evidence of the original power that is vested in the office of the in loco parentis person.

When a pupil is excluded from school, it is clearly a case of group interests weighing heavier than the interests of an individual.

\subsection{Duty of care}

The teacher as an in loco parentis person has an obligation to watch over the safety of the pupil (the child of his associate - the parent). The teacher is responsible for the pupil's safety for the duration of school activities. Prinsloo (1989:53) referring to court decisions, shows that this duty of care includes the physical and psychological welfare of the pupil under his control. The degree of prudence legally expected from the in loco parentis person, is basically that of the diligent paterfamilias (the diligent father of a family) (Rusere $v$ The Jesuit Fathers 19704 539). It means that the teacher should 
care (and protect) the pupils under his control like a diligent (or good) father would have watched over his children. The protection of his associate's child serves as a good example of co-operation between the associates.

Van Wyk (1987:90) makes it clear that where pupils are injured the teacher could be liable if there is negligence on the part of the teacher. The legal principles concerning negligence are derived from common law. One of the important criterions to determine the negligence of a person, is the reasonable man-test or the test for reasonable foreseeability. This test basically asks the question whether a reasonable man would have (Van Wyk, 1987:90)

foreseen that his act (or failure to act) would have resulted in damage (or injury) to the other person;

- taken reasonable steps to prevent damage (or injury) to the other person.

Typical areas of danger for the pupil during school activities are on the plavground, the sportfield, physical education classes, swimming-pool and classrooms (especially laboratories and workshops) (Oosthuizen, 1988:94).

\section{CONCLUSION}

The position of the teacher as an in loco parentis person is based on his relationship with his associate, the parent of the pupils under his control, as well as his office as a teacher.

This position does not only consist of duties and liabilities towards his associate - the parent - and his child; it also empowers him as an authority to maintain order and discipline within the school milieu.

Whilst the present situation of parent-teacher partnership is defined as a voluntary association, the question arises whether the present system should be maintained or whether it should be reorganised to meet the requirements of a true partnership. Against the background of the present trend towards the devolution of power to local communities, the legally well-defined essentials of the partnership could provide a stronger mobility to parent-teacher co-operation and at the same time still accommodate the autonomous roles of the parent and the teacher as an in loco parentis person. One of the aspects which is likely to be devolved to local schools (especially in private and semi-private schools) is most likely that of finances. The legalised mobility and profit-making objects of the partnership will suit the non-statutory bodies very well 
in this respect. In the statutory bodies the legal basis of the partnership will structure the rights and obligations of the associates in a much more structured manner. The contents of a partnership agreement (which is a prerequisite to the partnership) could not only structure and specify co-operation within the statutory bodies, but also within the (sometimes legally loosely-based) present loosely-based non-statutory bodies.

\section{BIBLIOGRAPHY}

BAMFORD, B. 1982. The Law of Partnerships and Voluntary Associations in South Africa. Cape Town : Juta \& Co.

BLACK, H.C, 1979, Black's Law Dictionary. Minesola : West Publishing.

BRAY. W, 1988. Juridiese aspekte van die onderwys-. sko()l- en klashestuut. Pretoria : Ĺnisa.

CLAASSEN, C.J. 1976. Dicuonary of Legal Words and Phrases. Durban : Butterworth

DE WET, J.C. \& VAN WYK, A.H. 1978. Kontraklereg en handelsreg. Durban : Butterworth

FELLMY, W. 1983. Kevs to Effective Disciphne. Making Rules Simple, Clear, Visible. NASSSP Bulletun, 67(402)(68:7(). April.

GRIESSEL. G.A.J 1975. Die gesagsverhouding in dite opvoedingslecr-perspekticf en fundamentek pedagogick-perspektief. Pretoria. (Procfskrif (D.Ed.) - Unisa.)

HOSTEN, W.J., EDWARDS. A.B.. NATHAN. (C. \& BOSMAN. F. 1979. Inlciding tol die SuidAfrikaanse reg en regslecr. Durban: Butterworth.

KAHN, E. ed. 1982. Family Guide to Law in South Africa. Cape Town : Reader's Digest.

LOUW, W.J. MOLLER. A.K., MENTZ. H.C. 1983. Verhandiegging in die didakliese pedagogiek Prctoria : Academica.

McDANIEL, T.R. 1986. A Primer on Classroom Disciplinc: Principles Old and New. Pludelea Cappan. $68(1): 63-67$

MENTZ, P.J. 19\%0. Organisasicklimaal in sekondere skole. Polchefsı room. (Proefskrif (D.Ed) - PU vir CHO.)

Orange Free State Provincial Division Law Reports 1925 (OPD 30)

OOSTHUIZEN, I.J. \& BONDESIO. M.J. 1988. Dic reg in dic onderwyspraklyk. Pretoria : Academica.

OOSTHUIZEN, 1.J. 1989. Die onderwyser en dic oucrgemeenskap. (In Bondesio, M.J., Beckmann, J.L., Oosthuizen, I.J., Prinsloo, J.G, Van Wyk, J.G. Juridicse tocrusling vir dic onderwysprofessic Pretoria : J.P. van der Walt. p. 101.)

OOSTHUIZEN, I.J. 1900. Ouer-onderwyservennootskap: konflik of koordinasie? Fokus 2000, 18:74-86, Okt.

PARTINGTON, J. 1984. Law and the New Teacher. London : Halt, Rinchart \& Winston.

POSTMA, F. s.j. Woordebock, Afrikaans-Latyn. Pretoria : HAUM.

PRINSLOO, J.G. \& BECKMANN, J.L. 1989. Die onderwys en dic regle en pligte van ouers, onderwysers en kinders. Johannesburg : Lex Patria.

SHRlgiLEY, R.L. 1985. Siudenı Disruption in the Class Room - Teachers Need Intervention Skills NASSP Bulletin, $69(4790): 26-32$, March.

SOUTH AFRICAN LAW REPORTS. 1925 OPD 30

SOUTH AFRICAN LAW REPORTS. 1948(4)SA $862(0)$

SOUTH AFRICAN LAW REPORTS, 1970(4)SA 532(T)

SOUTH AFRICAN LAW REPORTS, 1970(4)SA 539(R).

SOUTH AFRICAN LAW REPORTS, 1982(2)SA 104 (BT)

SOUTH AFRICA (REPUBLIC). Education Affairs Act, no. 70 of 1988. Pretoria : Government Printer.

SOUTH AFRICA (REPUBLIC). National Education Policy Acl, no. 37 of 1967. 
The in loco parentis role of the teacher: a relationship perspective

SOUTH AFRICA (REPUBLIC), 1990. Rcgulations Relating to the Education Affairs Act. Govemment Gazette, 12381:297, March 1990. (Regulation Gazctte no. 4475).

VAN DER WALT, J.L. \& DEKKER, E.I. 1982. Fundamentele Opvoedkunde vir die onderwysstudente. Prctoria : Promedia.

VAN DER VYVER, J.D. \& JOUBERT, D J. 1985. Persone- en Familiercg. Kaapstad : Jula en kic. VAN WYK, J.G. 1987. The Law of Education for the Teacher. Pretoria : Academica. 